\title{
Konseling Behavioral Dalam Meningkatkan Konsentrasi Belajar Peserta Didik Sekolah Menegah Pertama Negeri 1 Hulu Sungkai Kabupaten Lampung Utara
}

\author{
Badrul Kamil, You Pensi Olvatika \\ Dosen dan Mahasiswa Fakultas Tarbiyah dan Keguruan, IAIN Raden Intan \\ Lampung Diterima: April 2015. Disetujui: Mei 2015. Dipublikasikan: Juni
}

2015

\begin{abstract}
Abstrak: Tujuan dari penelitian ini adalah untuk mengetahui apakah konseling kelompok dengan tekhnik selfmanagement dapat meningkatkan rasa percaya diri peserta didik SMPN 1 Hulu Sungkai Kabupaten Lampung Utara. Penelitian ini menggunakan metode eksperiment dengan desain One-Group Pretest-Postttest. Sampel penelitian sebanyak 10 peserta didik diambil dengan menggunakan tekhnik Purposive Sampling. Pengumpulan data dilakukan dengan menggunakan tekhnik angket berupa skala tentang konsentrasi belajar dan observasi. Hasil penelitian menunjukkan bahwa hipotesis Ha diterima sedangkan hipotesis Ho ditolak. Ini terbukti dengan hasil analisis data dengan menggunakan uji-t prestest dan posttest diperoleh 49 dan posttest 77,3. Hasil penelitian ini menyimpulkan bahwa konseling kelompok dengan tekhnik self-management dapat meningkatkan konsentrasi belajar peserta didik SMPN 1 Hulu Sungkai Kabupaten Lampung Utara.
\end{abstract}

Kata Kunci : Konseling Behavioral, Tekhnik Self-Management, Konsentrasi Belajar

\section{Pendahuluan}

Dalam keseluruhan proses pendidikan, kegiatan belajar dan mengajar merupakan kegiatan yang paling pokok. Hal ini berarti bahwa berhasil tidaknya pencapaian tujuan pendidikan banyak bergantung kepada bagaimana proses belajar mengajar dirancang dan dijalankan secara profesional. (Pupuh Fathurrohman, 2010) Proses pembelajaran dikatakan berhasil manakala tujuan pembelajaran tercapai. Berhasil tidaknya pencapaian tujuan pembelajaran bergantung pada proses pembelajaran bergantung pada proses pembelajaran yang dijalani oleh peserta didik.

Peserta didik adalah subjek utama pendidikan. Secara sederhana peserta didik adalah seorang yang sedang ingin mengetahui sesuatu hal yang baru. Setiap peserta didik mempunya keterampilan yang berbeda-beda dalam hal belajar, seperti keterampilan membaca, mendengar, dan menulis yang diperoleh dari pengalaman balajar yang sudah pasti akan berpengaruh dengan prestasi belajar. Dengan prestasi belajar yang tinggi berarti suatu tujuan dari kegiatan belajar mengajar tercapai dengan baik. Setiap guru tentunya akan berusaha semaksimal mungkin memberikan materi belajar sesuai kebutuhan peserta didiknya agar mereka mencapai prestasi secara optimal. Untuk mencapai kompetensi peserta didik secara optimal. Untuk mencapai kompetensi peserta didik secara optimal diperlukan kerja sama yang baik antara manajemen, pengajaran, dan konseling yang merupakan tiga pilar pendidikan. (Nurihsan, 2012).

Bimbingan dan konseling memiliki peranan penting di lingkungan sekolah karena merupakan bidang layanan pokok setelah kurikulum dan pengajaran. Pelayanan bimbingan dan konseling di sekolah memberikan perhatian utama dan menyelenggrakan pelayanan yang secukup- cukupnya untuk pada peserta didik agar mereka mampu berkembang dan belajar secara optimal. (Amti, 2008) dalam bimbingan konseling peserta didik dibantu begitu saja 
dalam memecahkan masalah yang sedang dihadapinya, tetapi dibantu dalam mengidentifikasi masalahnya. (Akhmad Muhaimin, 2011)

Menurut Asmani dalan Abdullah "ada dua indikator yang dapat dijadikan sebagai tolak ukur keberhasilan proses belajar yaitu daya serap terhadap pelajaran dan perubahan prilaku peserta didik. Salah satu faktor yang dapat mempengaruhi rendahnya daya serap peserta didik adalah konsentrasi." (Malawi, 2015)

Menurut Slameto dalam Amalia "konsentrasi adalah pemusatan pemikiran terhadap suatu hal dengan menyampingkan semua hal lainnya yang tidak berhubungan. Dalam belajar konsentrasi berarti pemusatan pemikiran terhadap suatu mata pelajaran dengan menyampingkan semua hal lainnya yang tidak berhubungan dengan pelajaran." (Setiani, 2015)

Berdasarkan pendapat tersebut konsentrasi merupakan hal penting yang harus dimiliki oleh setiap peserta didik karena dengan konsentrasi peserta didik mampu fokus dan memahami pelajaran yang diberikan dengan menyampingkan semua hal yang di luar pelajaran. Artinya setiap tindakan atau pekerjaan yang peserta didik lakukan tersebut dilakukan dengan sungguhsungguh dan memusatkan seluruh perhatiannya dalam belajar. Sehingga peserta didik dapat berkonsentrasi belajar dalam melakukan proses belajar mengajar. Dalam psikologi umum dalam Diana konsentrasi adalah kemampuan untuk memusatkan pikiran terhadap pikiran aktivitas belajar. (Aprilia, 2015)

Guru sebagai sosok sentral dalam kegiatan pelajaran tentunya merupakan sosok yang sangat berpengaruh terhadap keberhasilan belajar peserta didik utamanya yang menggunakan jalur pendidikan formal. Oleh karena itu, guru harus memiliki pengetahuan minimal tentang teori belajar maupun mengajar sebagai pegangan dalam praktek. (Ali, 2004) guru menciptakan suasana kelas yang menyenangkan merupakan salah satu cara untuk membuat peserta didik semangat mengikuti proses belajar mengajar sehingga dapat menarik perhatian dan minat peserta didik untuk memperhatikan guru di kelas. Dengan demikian, suasana kelas yang tidak monoton dan kondusif membuat peserta didik dapat berkonsentrasi belajar. Menurut Jean Peaget dalam Diana Aprillia menyatakan indikator belajar yaitu:

1. Prilaku kognitif, ditengarahi dengan: a. kesiapan pengetahuan yang dapat segera muncul bila diperlukan; b. komprehensif dalam penafsiran informasi; c. mengaplikasikan pengetahuan yang diperoleh. Mampu mengadakan analisis dan sintesis pengetahuan yang diperoleh.

2. Prilaku afektif, ditengarahi dengan:a. perhatian pada materi pelajaran; b. merespon bahan yang diajarkan; dan c. mengemukakan suatu ide.

3. Prilaku psikomotor, ditengarahi dengan: a. adanya gerakan anggota badan yang tepat atau sesuai dengan petunjuk guru; b. komunikasi non verbal seperti ekspresi muka dan gerakangerakan yang penuh arti; dan c. adanya aktivitas berbahasa yang terkoordinasi dengan baik dan benar. (Aprilia, 2015)

Berdasarkan pendapat tersebut, konsentrasi dapat dilihat dari prilaku kognitif, perilaku afektif dan prilaku psikomotornya. Peserta didik dapat dikatakan konsentrasi belajar melihat dari indikatordan sub indikator. Namun kenyataannya ketika peneliti melakukan observasi di SMP Negeri 1 Hulu Sungkai pada saat belajar mengajar, peserta didik kurang konsentrasi saat mengikuti proses belajar mengajar karena pada kenyataannya yaitu kondisi peserta didik di kelas tersebut kurang kondusif dan dapat dikatakan belum mampu untuk berkonsentrasi belajar. Banyak peserta didik yang kurang merespon bahan yang diajarkan, tidak memperhatikan guru bidang studi dalam proses belajar mengajar, dan terganggu karena teman sebangku, sulit memahami pelajaran dan tidur di atas meja. Hal ini menyebabkan tidak efektifnya belajar mengajar sehingga pembelajaran tidak diterima dengan baik oleh peserta didik. Ini juga diperkuat oleh data yang saya dapatkan dari sekolah tersebut yaitu data peserta didik kelas VIII yang berjumlah 120 peserta didik dari 3 kelas yang ada di SMP Negeri 1 Hulu Sungkai Lampung Utara yang memiliki masalah konsentrasi belajar yang peneliti dapatkan dari 
dokumen guru BK.

Upaya yang telah dilakukan oleh pihak sekolah untuk mengatasi konsentrasi belajar belum maksimal, salah satunya adalah memberikan pengarahan dan layanan informasi oleh guru bimbingan konseling pada semua peserta didik. Nemun hal ini kurangnya respon dan kerja sama dengan guru mata pelajaran. Banyak dijumpai bahwa guru matapelajaran menganggap apa yang dilakukan oleh peserta didik tersbut wajar. Ketika peserta didik yang mengikuti pelajaran dalam kelas dianggap sudah cukup tanpa memperdulikan apakah peserta didik tersebut fokues dan memahami pelajaran yang diberikan. Masalah ini tidk dapat dibiarkan karena akan berdampak tidak baik bagi peserta didik itu sendiri, ketidakpedulian mereka akan membuat mereka kurangnya konsentrasi belajar tanpa tahu betapa pentingnya konsentrasi itu sendiri. Hal ini terasa penting sekali, sebab proses belajar hanya akan berhasil dengan baik, apabila peserta didik berada dalam keadaan sejahtera, sehat dan dalam suasana tahap perkembangan yang optimal. (A., 2005)

Berdasarkan fenomena yang ditemukan di SMP Negeri 1 Hulu Sungkai Lampung Utara ini, peneliti berupaya menerapkan layanan konseling behavioral dengan tekhnik selfmanagement yang tepat dalam membantu peserta didik untuk mengatasi konsentrasi belajar. Dalam layanan ini dilakukan secara kelompok karena masing-masing peserta didik dapat saling berhubungan dan berkomunikasi antar anggota kelompok dengan berbagi pengalaman, pengetahuan, ide-ide atau gagasan dan dapat membantu peserta didik untuk mengatasi konsentrasi belajar peserta didik. Selain untuk menghadapkan konsentrasi belajar peserta didik pada permasalahan yang ada dan memecahkannya secara bersama-sama.

Menurut prayitno dalam Riezka Ratna mengatakan "layanan konseling kelompok pada dasarnya adalah layanan konseling perseorangan yang dilaksankan di dalam suasana kelompok. Disana ada konselor dan ada peserta didik, yaitu para anggota kelompok (yang jumlahnya minimal dua orang). Disana terjadi hubungi konseling dalam suasana yang diusahakan sama seperti dalam konseling perseorangan yaitu hangat, permisif, terbuka dan penuh keakraban. Dimana juga ada pengungkapan dan pemahaman masalah klien, penelusuran sebab-sebab timbulnya masalah, upaya pemecahan masalah (jika perlu menerapkan metodemetode khusus) kegiatan evaluasi dan tindak lanjut. (Syamsuddin, 2015)

Berdasarkan penjelasan tersebut bahwa layanan konseling kelompok dapat memberikan kekuatan untuk masing-masing peserta didik. Dalam konseling kelompok sama halnya dengan konseling individu yang memberikan kehangatan, permisif, terbuka dan penuh keakraban dalam memanfaatkan dinamika kelompok. Selain itu, dengan adanya konseling kelompok peserta didik mampu mengendalikan diri dan menahan emosi, dapat bertenggang rasa dan menjadi akrab satu sam alainnya. Terdapat topik tugas dalam pelaksanaan konseling kelompok yang akan dibahas bersama-sama dengan anggota kelompok yang memerlukan konsentrasi yang maksimal untuk dapat membahas topik tersebut secara tuntas. (Syamsuddin, 2015) dalam hal ini peserta didik tersebut didorong untuk melakukan tindakan yang selaras dengan kemampuannya semaksimal mungkin melalui prilaku perwujudan diri. (Supriatna, 2011)

Selain itu cara yang dapat digunkan untuk mengatasi gangguan konsentrasi belajar peserta didik yaitu dengan pendekatan konseling behavioral. Pendekatan behavioral menekankan kajian ilmiah mengenai berbagai respon prilaku yang dapat diamati dan penentu lingkungan. Dengan kata lain, pendekatan prilaku memusatkan pada interaksi dengan lingkungan yang dapat dilihat dan diukur. (King, 2010) tekhnik konseling yang digunakan dalam mengatasi konsentrasi belajar dalam konseling yang digunakan dalam konseling behavioral ini adalah tekhnik self management. Pendekatan behavioral dengan tekhnik selfmanagement dimaksudkan untuk mencegah berkembangnya masalah konsentrasi dalam diri peserta didik dalam membuat rencana dan keputusan yang tepat. Selain itu, melalui tekhnik ini peserta didik diharapkan mendapat suatu dorongan untuk menunjukkan siapa diri mereka sebenarnya. Peserta didik dapat mendorong diri sendiri untuk maju, dapat mengatur dan 
mengevaluasi dirinya sendiri dalam mencapai perubahan yang diinginkan baik internal maupun eksternal.

Tahap-tahap dari Self-Management itu sendiri adalah sebagai berikut: 1) tahap monitor diri atau observasi; 2) tahap evaluasi diri; 3) tahap pemberian penguatan, penghapusan dan hukuman. (Gunarsa, 2011) sedangkan menurut Cormier dalam Mochamad Nursalim terdapat tiga strategi self-management, yaitu: 1) self-monitoring, 2) stimulus control, dan 3) self-reward

\section{Metode Penelitian}

Adapun sampel dalam penelitian ini adalah kelas VIII A, B, dan C dengan jumlah 10 peserta didik diambil dengan menggunakan purposive sampling (tekhnik penentuan sampel dengan pertimbangan tertentu). Pengambilan sampel dengan cara penyebaran angket dan dipilih peserta didik yang mengalami konsentrasi belajar. Kriteria peserta didik yang dijadikan sampel ialah peserta didik yang mengalami konsentrasi belajar yang rendah salah satunya seperti tidak fokus saat belajar, ketidaksiapan peserta didik dalam belajar, adanya gerakan anggota tubuh yang tidak diinginkan, dan adanya aktivitas yang tidak terkoordinasi dengan baik dan benar. Sedangkan populasi dalam penelitan ini adalah terdiri dari 3 kelas VIII A, B, dan $\mathrm{C}$ sebanyak 120 peserta didik.

Jenis penelitian yang dilakukan adalah penelitian eksperimen yang dimaksudkan benarbenar untuk melihat hubungan sebab-akibat. Perlakuan yang dilakukan terhadap variabel bebas kita lihat hasilnya pada variabel terikat. Sehingga peneliti melakukan perlakuan terhadap varibel bebas dan mengamati perubahan pada variabel terikat. Selanjutnya menurut Sugiyono bahwa "metode penelitian eksperimen adalah metode penelitian yang digunakan untuk mencari pengaruh perlakuan tertentu terhadap yang; lain dalam kondisi yang terkendalikan. (Sugiyono, 2011) konsentrasi belajar menggunakan konseling kelompok dengan pendekatan behavioral tekhnik self-management.

Dari hasil pretest dan postest diperoleh dari observasi dengan jawaban angket yang diberikan kepeserta didik kelas VIII sebelum dan sesudah konseling. Berikut data yang diperoleh:

Tabel 1. Hasil Pretest dan Posttest

\begin{tabular}{|c|c|c|c|c|}
\hline NO & $\begin{array}{c}\text { Nama } \\
\text { (Inisial) }\end{array}$ & Pretest & Posttest & $\begin{array}{c}\text { Gain (d) Posttest dan } \\
\text { Pretest }\end{array}$ \\
\hline 1 & L & 49 & 82 & 33 \\
\hline 2 & FL & 47 & 70 & 23 \\
\hline 3 & FF & 51 & 81 & 30 \\
\hline 4 & UT & 51 & 79 & 28 \\
\hline 5 & TS & 50 & 80 & 30 \\
\hline
\end{tabular}




\begin{tabular}{|c|c|c|c|c|}
6 & DI & 46 & 78 & 32 \\
\hline 7 & HK & 50 & 74 & 24 \\
\hline 8 & LU & 49 & 78 & 29 \\
\hline 9 & AD & 48 & 76 & 28 \\
\hline 10 & GJ & 49 & 75 & 26 \\
\hline \multicolumn{2}{|c|}{$\mathrm{N}=10$} & $\sum=490$ & $\sum 1=773$ & $\sum \mathrm{d}=283$ \\
\hline \multicolumn{2}{|c|}{} & $\mathrm{X} 1=$ & $\mathrm{X} 1=$ & \\
& & $490 / 10$ & $773 / 10$ & $\mathrm{Md}=\sum \mathrm{d} / \mathrm{N} 283 / 10=28,3$ \\
\cline { 3 - 3 } & & 49 & 77,3 & \\
\cline { 3 - 4 } & & & & \\
\hline
\end{tabular}

Adapun desain penelitian menggunakan pre-eksperimental designs dengan bentuk onegorup pretest-posttest design yaitu desain yang memberi pretest sebelum diberikan perlakuan dan memberi posttest setelah diberi perlakuan dapat lebih akurat, karena dapat membandingkan dengan keadaan sebelum diberi perlakuan dan dapat diketahui antara kondisi sebelum dan sesudah diberi perlakuan.

\section{Hasil Dan Pembahasan}

Hasil dengan judul konseling behavioral dalam meningkatkan konsentrasi belajar peserta didik Sekolah Menengah Pertama Negeri 1 Hulu Sungkai Kabupaten Lampung Utara. Sebelum hasil penelitian diperoleh, peneliti menyebarkan instrumen penelitian kepada peserta didik dengan tujuan untuk memperoleh gambaran konsentrasi peserta didik kemudian diberi perlakuan. Populasi dalam penelitian ini berjumlah 120 peserta didik kelas VIII. Hasil penelitian terdiri dari profil/gambaran menjelaskan bahwa konseling behavioral memiliki empat tahap: melalakukan assesmen (assesment), menentukan tujuan (goal setting), implementasi tehnik (technique implementation), evaluasi dan pengakhiran (evaluationtemination).

Berdasarkan tabel tersebut diketahui bahwa skor pretest 49 dan posttest 77,3. Hal ini membuktikan bahwa terjadinya peningkatan sebesar 28,3. Artinya konsentrasi peserta didik 
meningkat setelah diberi konseling behavioral dengan tekhnik self-management. Berdasarkan hasil uji hipotesis dinyatakan bahwa konsentrasi belajar peserta didik kelas VIII meningkat sebesar 28,3 sehingga Ho ditolak dan Ha diterima. Dengan demikian, hipotesis dapat dikatakan adanya peningkatan konsentrasi belajar pada peserta didik melalui konseling behavioral dengan tekhnik self-management dapat diterima. Peningkatan dan perubahan terhadap konsentrasi belajar ini didukung oleh observasi yang dilakukan oleh teman dan guru yang menunjukkan bahwa konsentrasi belajar peserta didik meningkat.

Kondisi konsentrasi belajar kelas VIII SMP Negeri 1 Hulu Sungkai tersebut, peneliti memberikan treatment berupa konseling kelompok. Pendekatan yang digunakan pada konseling kelompok adalah pendekatan behavioral dengan tekhnik self-management. Setelah mendapatkan treatment, diketahui bahwa konsentrasi belajar peserta didik meningkat.

Meningkatkan konsentrasi belajar peserta didik melalui konseling kelompok menggunakan pendekatan behavioral dengan tekhnik self-management dilakukan melalui beberapa tahap konseling dengan lima kali pertemuan. Ada empat tahap dalam layanan konseling kelompok yang dilakukan peneliti. Hal tersebut sesuai dengan pendapat Rosjidan dalam Haris Handoko yang mengatakan bahan konsentrasi dapat dilihat pada prilaku kognitif, afektif, dan psikomotor. (Aprilia, 2015)

\section{Kesimpulan}

Berdasarkan hasil penelitian dan pembahasan disimpulkan bahwa terdapat peningkatan konsentrasi belajar peserta didik setelah diberikan konseling kelompok dengan tekhnik selfmanagement. Hasil perhitungan pretest dan posttest menunjukkan terdapat perbedaan positif mengenai konsentrasi belajar peserta didik, ini terlihat dari hasil pretest sebesar 49 dan hasil posttest meningkat menjadi 77,3. Hal ini menunjukkan bahwa adanya peningkatan konsentrasi belajar pada peserta didik setelah dilakukan konseling kelompok dengan tekhnik selfmanagement meningkat 28,3. Jadi dapat disimpulkan bahwa konseling kelompok dengan tekhnik self-management dapat meningkatkan konsentrasi belajar kelas VIII SMPN 1 Hulu Sungkai Kabupaten Lampung Utara tahun pelajaran 2015/2016.

\section{Daftar Pustaka}

A., H. (2005). Bimbingan dan Konseling. Jakarta: Quantum Teaching.

Akhmad Muhaimin, A. (2011). Bimbingan dan Konseling di Sekolah. Yogyakarta: Ar-ruzz Media.

Ali, M. (2004). Guru Dalam Proses Belajar Mengajar. Bandung: Sinar Baru Algesindo.

Amti, P. d. (2008). Dasar-dasar Bimbingan Konseling. Jakarta: Rineka Cipta.

Aprilia, D. (2015, maret 20). Retrieved from Penerapan Konseling Kognitif Dengan Tekhnik Pembuatan Kontrak (Contingency Contracting) untuk Meningkatkan Konsentrasi Belajar Siswa: http://ikippgrimadiun.ac.id/ejournal/s ites/default/files/1_diana aprilia\%20tristiar- konselingkognitif.pdf

Aprilia, D. (2015, september 16). Retrieved from Penerapan Konseling Kognitif Dengan Tekhnik Pembuatan Kontrak (Contingency Contracting) Untuk Meningkatkan Konsentrasi Belajar

Gunarsa, S. D. (2011). Konseling dan Psikoterapi. Jakarta: Libri.

King, L. A. (2010). Psikologi Umum Sebuah Pandangan Apresiatif. Jakarta: Salemba 
Humanika.

Malawi, I. (2015, februari 19). Retrieved from Pengaruh Konsentrasi dan Kemampuan Berpikir Kritis Terhadap Prestasi Belajar: http://ikippgrimadiun.ac.id/ejournal/s ites/default/files/1_ibadullah\%20trist iar-konsentrasibelajar.pdf,[Online],

Nurihsan, A. J. (2012). Strategi Layanan Bimbingan dan Konseling . Bandung: Refika Aditama.

Pupuh Fathurrohman, S. S. (2010). Strategi Belajar Mengajar. Bandung: Aditama.

Setiani, A. C. (2015, Februari, 19). Retrieved from Meningkatkan Konsentrasi Belajar Melalui Layanan Bimbingan Kelompok: http:/lib.unnes.ac.id/20064/1/13014 09037.pdf

Sugiyono. (2011). Metode Penelitan Kuantitatif dan Kualitatif dan $R \& D$. Bandung: Alfabeta.

Supriatna, M. (2011). Bimbingan Konseling Berbasis Kompetensi: Orientasi Dasar Perkembangan Profesi Konselor. Jakarta: PT. Raja Grafindo Persada.

Syamsuddin. (2015, maret 14). Retrieved from http://bangsyam.blogspot.com/ 
